\title{
Urinary albumin excretion rate and glomerular filtration rate in single-kidney type 2 diabetic patients ${ }^{1}$
}

\author{
Sandra P. Silveiro², Luciana da Costa ${ }^{2}$, Maristela O. Beck², \\ Jorge L. Gross ${ }^{2}$
}

OBJECTIVE: To evaluate the urinary albumin excretion rate and the glomerular filtration rate of single-kidney type 2 diabetic patients and of single-kidney nondiabetic patients. PATIENTS AND METHODS: Patients who had only one kidney for at least 5 years, with no renal disease or hypertension at the time of the nephrectomy and with no calculus or systemic disease at the time of the evaluation, were included in this controlled cross-sectional study. A total of 20 single-kidney type 2 diabetic patients (eight men, age $62 \pm 9$ years; diabetes duration $8.5 \pm 7$ years), 17 single-kidney nondiabetic patients (two men, age $57 \pm 13$ years), and 184 type 2 diabetic patients who were matched to the single-kidney diabetic group for age, sex and body mass index were studied. Urinary albumin excretion rate was measured by immunoturbidimetry in timed 24 - $h$ sterile urine, and glomerular filtration rate was determined by the ${ }^{51}$ CrEDTA single-injection method.

RESULTS: Single-kidney type 2 diabetic patients presented a higher proportion (eight of $20 ; 40 \%$ ) of microalbuminuria (urinary albumin excretion rate $20-200 \mathrm{mg} / \mathrm{min}$ ) than single-kidney nondiabetic patients (three of 17; 17.6\%) and type 2 diabetic patients (37 of 184; 20\%). Single-kidney diabetic patients presented a higher proportion of macroalbuminuria (urinary albumin excretion rate $>200 \mathrm{mg} / \mathrm{min}$; six of 20; 30\%) than single-kidney nondiabetic patients (one of 17; 6\%) but were similar to type 2 diabetic patients (43 of 184; 23\%). The glomerular filtration rates of normaoalbuminuric singlekidney nondiabetic patients $\left(71.7 \pm 21.4 \mathrm{ml} \times \mathrm{min}^{-1} \times 1.73 \mathrm{~m}^{-2}\right)$ and single-kidney type 2 diabetic patients $\left(73.0 \pm 21.5 \mathrm{ml} \times \mathrm{min}^{-1} \times 1.73 \mathrm{~m}^{-2}\right)$ were similar but higher than the one-kidney glomerular filtration rate (GFR $\div 2)$ of the age-, sex-, and body mass index-matched normoalbuminiric type 2 diabetic patients $\left(54.0 \pm 11.6 \mathrm{ml} \times \mathrm{min}^{-1} \times\right.$ $\left.1.73 m^{-2}\right)$.

CONCLUSIONS: Increased GFR related to single-kidney status confers an increased risk of developing renal disease in the presence of diabetes.

Key-words: UAER; GFR; type 2 diabetes; single kidney patients.

Taxa de excreção urinária de albumina e taxa de filtração glomerular em pacientes com diabetes tipo 2 e apenas um rim OBJETIVO: Avaliar a taxa de excreção urinária de albumina e a taxa de filtração glomerular em pacientes com apenas um rim e diabetes tipo 2 e em pacientes não-diabéticos com apenas um rim.

Este artigo foi publicado originalmente em Diabetes Care 1998;21:1521-4.

Departamento de Endocrinologia, Hospital de Clínicas de Porto Alegre, Porto Alegre, RS Brasil.

Correspondência: Dr. Jorge Luiz Gross, Rua Ramiro Barcellos 2350, sala 2030, CEP 90035-003, Porto Alegre, RS,

Brasil.Email: gross@hotnet.net 
PACIENTES E MÉTODOS: Foi feito um estudo controlado, de corte transversal. Este estudo incluiu pacientes que tivessem apenas um rim por, pelo menos, 5 anos, que não apresentaram doenças renais ou hipertensão quando da nefroctomia, e que não tivessem cálculo ou doença sistêmica quando da avaliação. Foram avaliados 20 pacientes com apenas um rim e diabetes tipo 2 (oito homens, idade $62 \pm 9$ anos; duração da diabete 8,5 \pm 7 anos), 17 pacientes não-diabéticos com apenas um rim (dois homens, idade $57 \pm 13$ anos), e 184 pacientes com diabetes tipo 2, que foram agrupados por idade, sexo e índice de massa corporal com os pacientes diabéticos com apenas um rim. A taxa de excreção urinária de albumina foi medida por imunoturbidimetria através de coletas de urina esterilizada obtidas a cada $24 \mathrm{~h}$. A taxa de filtração glomerular foi determinada pelo método ${ }^{51} \mathrm{Cr}-\mathrm{EDTA}$ de injeção única.

RESULTADOS: Os pacientes com diabetes tipo 2 e apenas um rim apresentaram uma proporção maior (oito em 20; 40\%) de microalbumnuria (taxa de excreção urinária de albumina $20-200 \mathrm{mg} / \mathrm{min}$ ) do que os pacientes não-diabéticos e com apenas um rim (três em 17; 17,6\%) e do que os pacientes diabéticos do tipo 2 (37 em 184, 20\%). Pacientes diabéticos com apenas um rim apresentaram uma proporção maior de macroalbuminuria (taxa de excreção urinária de albumina 200 mg/min; seis em 20; 30\%) do que os pacientes não-diabéticos e com apenas um rim (um em 17; 6\%), mas semelhante à mesma proporção dos pacientes com diabetes tipo 2 (43 em 184; 23\%). As taxas de filtração glomerular dos pacientes não-diabéticos e normoalbuminúricos com apenas um rim $\left(71,7 \pm 21,4 \mathrm{ml} \times \mathrm{min}^{-1} \times 1,73 \mathrm{~m}\right.$ $\left.{ }^{2}\right)$, e de pacientes com diabetes tipo 2 e apenas um rim $(73,0 \pm 21,5 \mathrm{ml} \times \mathrm{min}$ $\left.1 \times 1,73 \mathrm{~m}^{-2}\right)$ foram semelhantes. No entanto, estas foram mais elevadas do que a taxa de filtração glomerular (TFR $\div 2$ ) dos pacientes com diabetes tipo 2 e normoalbuminúricos, agrupados por idade, sexo e índice de massa corporal $\left(54,0 \pm 11,6 \mathrm{ml} \times \mathrm{min}^{-1} \times 1,73 \mathrm{~m}^{-2}\right)$.

CONCLUSÕES: Uma TFR elevada, associada à condição de um único rim, confere um aumento do risco de desenvolvimento de doença renal na presença de diabetes.

Unitermos: taxa de excreção urinária de albumina (UAER); TFR; diabetes tipo 2; pacientes com apenas um rim.

\section{Introduction}

Abnormalities in glomerular hemodynamic homeostasis have been proposed as the main determining factor to initiate and continue the progression of renal disease (1). Increased glomerular filtration rate (GFR) is the most commonly used marker of these changes. Glomerular hyperfiltration has been suggested as a risk factor for the development of diabetic nephropathy in type 1 diabetic patients (2), but the data are still contradictory (3-5). Few prospective studies on type 2 diabetic patients are available, and the results are still inconclusive $(6,7)$. Perhaps some of this controversy could be attributed to the lack of a more meaningful definition of glomerular hyperfiltration, since most authors define hyperfiltration as GFR values above the upper limit of the normal range (mean +2 SD) and this could be a rather arbitrary criterion. The single-kidney condition is characterized by hyperfiltration and can, therefore, be employed as a model for the study of the effects of glomerular hyperfiltration. Experimental studies incriminate glomerular hypertension in mediating progressive renal 
damage after uninephrectomy (8). Most of the studies came to the conclusion that uninephrectomy in men does not induce adverse effects on the remnant kidney. These studies did not include a representative number of diabetic patients $(9,10)$. Probably, the presence of diabetes increases the harmful potential of the single-kidney condition for renal function. To examine the consequences of the single-kidney status for kidney function (GFR and urinary albumin excretion rate, UAER), single-kidney individuals with and without diabetes were evaluated.

\section{Patients and methods}

A cross-sectional study was conducted on single-kidney patients with type 2 diabetes (SKD), single-kidney nondiabetic patients (SKN), and type 2 diabetic patients with two kidneys. The study was performed at the outpatient diabetes clinic at Hospital de Clínicas de Porto Alegre (HCPA) (a tertiary care center) between January 1995 and December 1996. Informed consent was obtained from each patient, and the protocol was approved by the ethics commitee. The diagnosis of diabetes and normal glucose tolerance was based on World Health Organization (WHO) criteria. The oral glucose tolerance test $(75 \mathrm{~g}$ of glucose) was performed in all nondiabetic patients after an overnight fast. The inclusion criterion for single-kidney patients (with or without diabetes) was the presence of only one kidney for at least 5 years. The presence of only one kidney was confirmed by renal scintigraphy (dimercapto succinic acid) and ultrasonography. Patients with renal disease (presence of overt proteinuria; $>0.5 \mathrm{~g} / 24 \mathrm{~h}$ or positive dipstick; and/ or serum creatinine $>1.2 \mathrm{mg} / \mathrm{dl}$ ) at the time of nephrectomy were excluded. Patients were also excluded if they presented calculus or systemic disease at the time of study evaluation.

A total of 20 type 2 diabetic patients with at least 1 year of diabetes duration and a previous known condition of one-kidney status (SKD patients) were recruited from the outpatient clinic at HCPA or from private clinics. The SKN patients were selected from a list of 365 patients who had undergone uninephrectomy at the hospital between 1975 and 1990. A total of 40 patients in the same age range as SKD patients were identified. Seventeen patients could not be located; three refused to participate in the study; and three patients presented abnormal glucose tolerance and were excluded from the study. A total of 184 type 2 diabetic patients were selected from a pool of about 500 type 2 diabetic patients attending the diabetes clinic, based on the same age range of SKD and SKN patients and on the same known duration range of diabetes of SKD patients.

All patients were submitted to a clinical evaluation. Smokers were defined as those currently smoking. Height and weight (light clothes without shoes) were measured and BMI was calculated (weight/height ${ }^{2}$ ). Blood pressure was measured twice in the sitting position after a 10-min rest with a mercury sphygmomanometer (phases I and V of the Korotkoff sounds). Arterial hypertension was considered to be present when systolic blood pressure was higher than $140 \mathrm{mmHg}$ or diastolic blood pressure was higher than $90 \mathrm{mmHg}$ or if the patient was taking antihypertensive drugs. In diabetic patients, the presence of retinopathy was assessed by an ophthalmologist by funduscopy after mydriasis. Absence of vibratory perception (tuning fork) and of ankle reflex and/or compatible symptoms were considered to represent peripheral neuropathy. Macroangiopathy was diagnosed by history and by clinical examination compatible with peripheral arterial, cerebrovascular, or coronary heart disease. The patients were evaluated at their usual diets, which corresponds to an average protein intake of $1.4 \mathrm{~g} / \mathrm{kg}$ body weight, assessed by diet records and nitrogen output.

Urinary albumin was measured in 24-h timed sterile urine samples by immunoturbidimetry (Microlab, Ames-Bayer, Tarrytown, NY) (intra-and interassay coefficients of variation 4.5 and $11.0 \%$, respectively). The presence of microalbuminuria or macroalbuminuria (confirmed at least twice) was established when the UAER was $20-200 \mu \mathrm{g} / \mathrm{min}$ or $>200 \mu \mathrm{g} / \mathrm{min}$, respectively (11). GFR was measured in the single-kidney patients and in a sample of 39 normoalbuminuric type 2 diabetic patients by the ${ }^{51} \mathrm{Cr}$-EDTA single-injection method (coeficient of variation 11.2\%) according to Chantler and Barrat (12). These normoalbuminuric type 2 diabetic patients were selected according to age, sex, and BMI from the normoalbuminuric patients $(n=104)$ of the whole group of type 2 diabetic patients $(n=$ 
184).The GFR values of 32 normal individuals (age $55.3 \pm 4.7$ years, range 48-66) were 100.9 $\pm 18.0 \mathrm{ml} \times \mathrm{min}^{-1} \times 1.73 \mathrm{~m}^{-2}$. Glucose was determined by a glucose oxidase method, creatinine by the Jaffé reaction, and fructosamine by a colorimetric method (normal range 1.87-2.87 $\mathrm{mmol} / \mathrm{l})$. These measurements were performed during the same day of GFR evaluation.

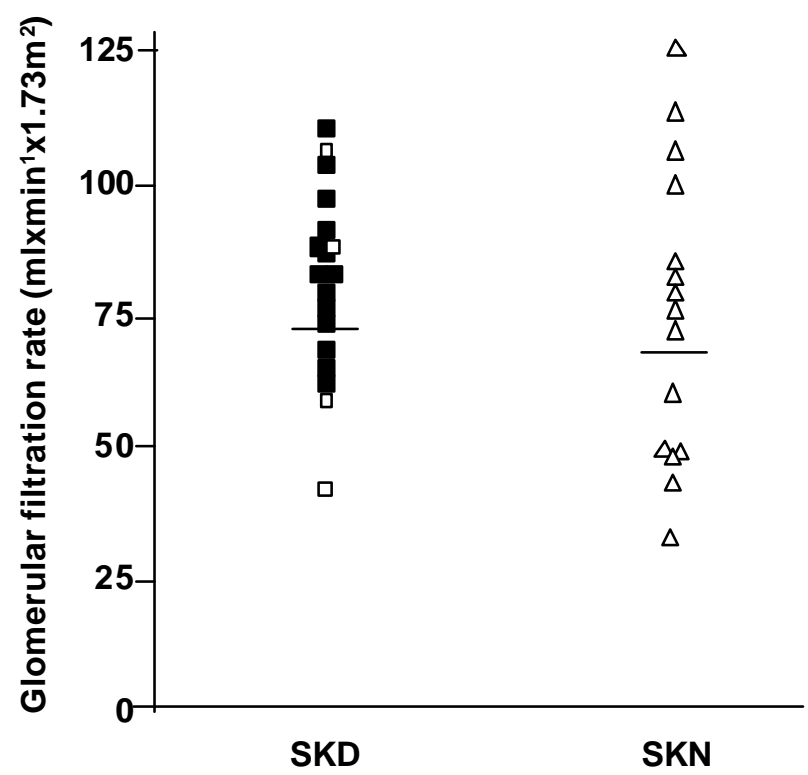

Figure 1. Glomerular filtration rate values of SKD patients and SKN patients. and $\Delta$ represent normoalbuminuric patients, and $\boldsymbol{\square}$ and $\boldsymbol{\Delta}$ represent micro- and macroalbuminuric patients.

\section{Statistical analysis}

UAER values were log-transformed before the calculations. Differences in mean values were tested by the unpaired $t$ test and by analysis of variance. Data were compared by the MannWhitney and Kruskal-Wallis tests. Proportions were compared by the Fisher's exact test and the $\chi^{2}$ test. $P$ values $<0.05$ were considered to be statistically significant. Results are expressed as means \pm SD unless otherwise stated. Statistical analysis was carried out with SAS and SPSS software packages.

\section{Results}

\section{Causes of single-kidney condition}

The causes of solitary-kidney condition were similar in SKD and SKN patients. Five of the SKD patients were considered to have renal agenesis, and the causes of uninephrectomy for the others were the following: infection (5), lithiasis (5) cancer (3), donation (1), and vascular abnormality (1). Three of the SKN patients were considered to have renal agenesis, and the reasons for uninephrectomy for the others was the following: donation (5), infection (4), lithiasis (2), cancer (2), and unknown (1). No significant difference in duration of the single-kidney condition was observed between SKD (means \pm SD [range]; $23 \pm 17$ years [5-63]) and SKN (21 \pm 18 [5-73], $P=0.64$ ) patients.

\section{Clinical and laboratory characteristics}

SKD, SKN, and type 2 diabetic patients were age-matched (age $62 \pm 9$ years [48-81]; 57 \pm 13 [35-75]; $61 \pm 7$ [48-75], respectively) and BMI-matched (28 $\left.\pm 4 ; 27 \pm 5 ; 28 \pm 5 \mathrm{Kg} / \mathrm{m}^{2}\right)$. They did not differ regarding smoking habit. The proportion of women was higher among SKN (15 of 17) patients than among type 2 diabetic patients (92 of 184) but was similar to that of SKD patients (12 of 20). Type 2 diabetic patients presented a higher proportion (113 of 184) of arterial hypertension than SKN patients (5 of 17; $P=0.01$ ), but not higher than that of SKD patients (9 of 20). SKD and type 2 diabetic patients presented the same known diabetes duration (8.5 \pm 7 years [1-22]; $10 \pm 7$ [1-34], respectively; $P=$ 0.47).

SKD and type 2 patients presented the same degree of metabolic control at the time of evaluation (fasting plasma glucose $9.7 \pm 4.4$ $\mathrm{mmol} / \mathrm{l}$ [3.6-22.0]; $9.8 \pm 4.1$ [2.6-24.0], respectively; fructosamine $3.41 \pm 0.74 \mathrm{mmol} / \mathrm{l}$ [2.52-5.04]; $3.40 \pm 0.84$ [2.00-7.00], respectively). There was no correlation between fasting plasma glucose and GFR in SKD patients $(r=0.22, P=$ $0.17)$.

\section{Renal data}

SKD patients presented a higher proportion of microalbuminuria (8 of $20,40 \%$ ) than SKN (3 of $17,17.6 \% ; P=0.03$ ) and type 2 diabetic (37 of $184,20 \% ; P=0.03$ ) patients and a higher proportion of macroalbuminuria (6 of $20,30 \%$ ) compared with SKN patients (1 of $17,6 \% ; P=$ $0.03)$. However, no difference was found in the 
proportion of macroproteinuria between SKD and type 2 diabetic patients (43 of 184, 23\%; $P=$ $0.19)$. The GFR values of normoalbuminuric SKD $\left(73.0 \pm 21.5 \mathrm{ml} \times \mathrm{min}^{-1} \times 1.73 \mathrm{~m}^{-2}\right)$ and SKN $(71.7$ $\pm 21,4 \mathrm{ml} \times \min ^{-1} \times 1.73 \mathrm{~m}^{-2}$ ) were not different

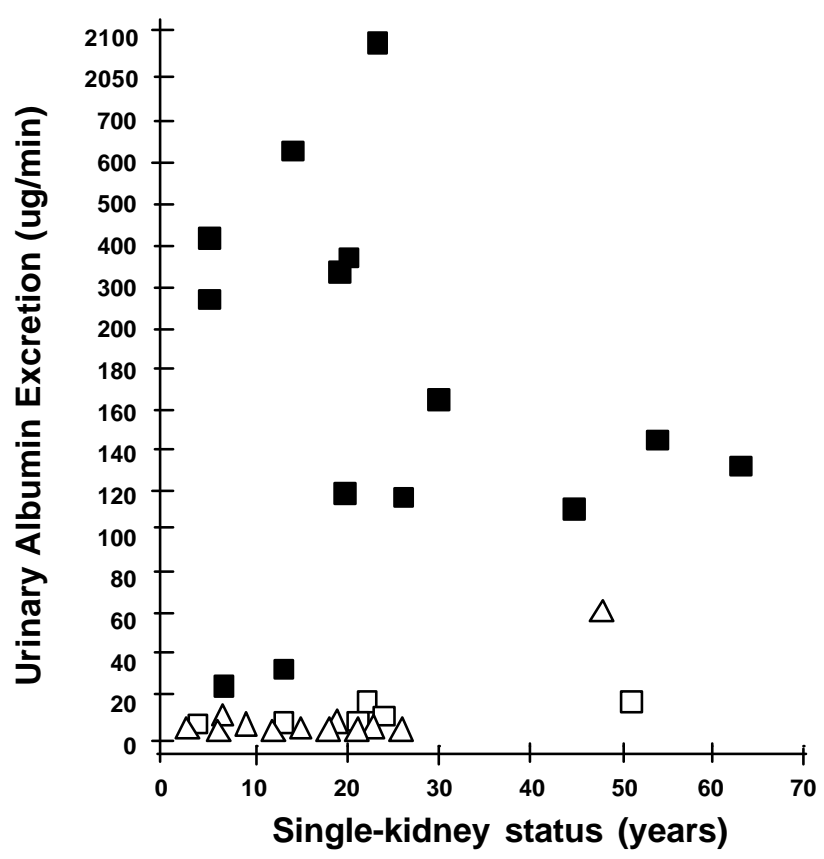

Figure 2. Urinary albumin excretion and number of years with one kidney in SKD patients $(\check{Z})$ and in SKN patients $(\Delta) . \bar{Z}$ and $\Delta$ represent normoalbuminuric patients, and and $\boldsymbol{\Delta}$ represent micro and macroalbuminuric patients.

(Figure 1). Assuming that each kidney accounts for $50 \%$ of total renal function, these values were higher than those of normoalbuminuric type 2 diabetic patients $\left(108.1 \pm 23.2 \mathrm{ml} \times \mathrm{min}^{-1} \times 1.73\right.$ $\left.\mathrm{m}^{-2} \div 2=54.0 \pm 11.6 \times \mathrm{min}^{-1} \times 1.73 \mathrm{~m}^{-2}\right)$ and normal individuals $\left(100.9 \pm 18.0 \mathrm{ml} \times \mathrm{min}^{-1} \times 1.73\right.$ $\left.\mathrm{m}^{-2} \div 2=50.5 \pm 9.0 \mathrm{ml} \times \mathrm{min}^{-1} \times 1.73 \mathrm{~m}^{-2}\right)$.

When analyzing the UAER and the duration of the single-kidney condition, we observed that three of four SKN patients who developed increased albuminuria did so after 30 years with one kidney. On the other hand, increased UAER was observed in SKD patients as early as after 5 years of single-kidney status (Figure 2).

Considering only SKD and SKN patients with increased UAER, the duration of the singlekidney condition was found to be shorter in SKD patients $(23.0 \pm 18.4$ vs. $43.5 \pm 23.2$ years; $P=$ 0.009 ). All SKD patients with more than 25 years of single-kidney condition presented increased UAER levels, except one patient with renal agenesis whose known duration of diabetes was 1 year. SKD and type 2 patients with elevated UAER presented similar age (63 \pm 10 vs. $62 \pm 7$ years, respectively), male-to-female ratio (8:6 vs. 30:50), BMI ( $29 \pm 5$ vs. $\left.28 \pm 5 \mathrm{~kg} / \mathrm{m}^{2}\right)$, known diabetes duration (10 \pm 7 vs. $12 \pm 8$ years), proportion of smokers (1:14 vs. 7:80), number of hypertensive patients ( 8 of 14 vs. 58 of 80 ), and degree of metabolic control (fasting plasma glucose $10.6 \pm 4.9$ vs. $10.7 \pm 4.7 \mathrm{mmol} / \mathrm{l}$; fructosamine $3.46 \pm 0.72$ vs. $3.55 \pm 0.89 \mathrm{mmol} /$ I). The prevalence of chronic complications of diabetes, such as retinophaty (54 vs. $76 \%$ ), peripheral neurophaty (23 vs. $54 \%$ ), and macrovascular disease (31 vs. $28 \%$ ) was similar for SKD and type 2 diabetic patients, respectively.

\section{Conclusions}

In the present study an increased proportion of microalbuminuria and macroalbuminuria in type 2 diabetic patients with only one kidney for at least 5 years was observed. This period of time was chosen as the minimum time required for the patients to be exposed to the risk (single-kidney). The interval of 5 years was based on the observation that microalbuminuria will develop only after 5 years of diabetes duration in type 1 patients (13). The elevated number of diabetic patients with renal disease may indicate that the glomerular hyperfiltration occurring in single-kidney patients has a pathogenic role in the development of diabetic nephropathy. The clinical and laboratory characteristics of the three groups of patients were similar, but the duration of single-kidney status was shorter in SKD patients than in SKN patients. Therefore, we may assume that the single-kidney condition predisposes to the appearance of increased UAER.

The GFR increases $40-60 \%$ in the remaining kidney a few weeks after nephrectomy (14). Our data are in accordance with this observation, considering the range of GFR in normal individuals and normoalbuminuric type 2 diabetic patients. The increase in GFR in uninephrectomized nondiabetic individuals is due to the increase in renal plasma flow (RPF) (14). In diabetic patients, the increase of RPF accounts for approximately $40 \%$ of the increase in GFR (15). Experimental studies have suggested that 
increased intraglomerular pressure also contributes to hyperfiltration, and it is probably the most important factor of initiating renal disease (16). Therefore, the mechanisms of hyperfiltration of nondiabetic single-kidney patients are probably not the same as those of diabetic patients.

It has been previously reported that GFR levels are influenced by metabolic control in type 2 diabetic patients, correlating positively with fasting plasma glucose in these patients (17). In SKD patients, this correlation was not observed, probably because GFR was already maximally elevated in patients with one kidney.

Previous studies on single-kidney patients included small numbers of diabetic patients. Schmitz et al. (9) found no detectable harmful effects on kidney function in patients with one kidney $(n=29)$, including three type 1 diabetic patients. Narkun-Burgess et al. (10), in a 45-year follow-up after traumatic uninephrectomy $(n=28)$, concluded that the procedure has few major adverse effects on the kidney. However, four out of five patients with some alteration of renal function in that study (serum creatinine $>1.5 \mathrm{mg}$ / dl or proteinuria $>250 \mathrm{mg} /$ day) also presented with type 2 diabetes. As far as we know, the current study is the largest one including diabetic patients with one kidney.

However, we should note that the proportion of macroalbuminuria in SKD patients was not different from that observed in type 2 diabetic patients. This could represent a bias of selection of type 2 diabetic individuals since this group was recruited from a tertiary care center with a special interest in diabetic nephrectomy. In fact, the proportion of macroalbuminuria in our type 2 diabetic patients was higher than that reported by other authors (14\%) (18). Using this figure, we observed that our SKD patients presented a higher proportion of macroalbuminuria $(P=0.02)$.

An important aspect to be solved is the meaning of the increased UAER in SKD and SKN patients. Microalbuminuric SKD patients are very similar to microalbuminuric type 2 diabetic patients regarding blood pressure levels, degree of metabolic control, and prevalence of other cronic complications of diabetes. Only a prospective analysis of these patients could determine if this increased UAER constitutes a risk factor for increased mortality or more advanced stages of diabetic nephropathy, as demonstrated in type 2 diabetic patients with two kidneys $(19,20)$.

Acknowledgments. This study was supported by grants from Hospital de Clínicas de Porto Alegre and Projeto de Apoio a Núcleos de Excelência. L.A.C. and M.B.O. were recipients of scholarship from Coordenação de Aperfeiçoamento do Pessoal de Nível Superior (CAPES), and S.P.S. was the recipient of a scholarship from Conselho Nacional de Desenvolvimento Científico e Tecnológico (CNPq).

\section{References}

1. Brenner BM, Meyer TW, Hostetter TH. Dietary protein intake and the progressive nature of kidney disease: the role of hemodynamically mediated glomerular injury in the pathogenesis of progressive glomerular sclerosis in aging, renal ablation, and intrinsic renal disease. N Engl J Med 1982;307:6529.

2. Morgensen CE. Early glomerular hyperfiltration in insulin-dependent diabetes and late nephropathy. Scand J Clin Lab Invest 1986;46:201-6.

3. Rudberg S, Persson B, Dahlquist G. Increased glomerular filtration rate as a predictor of diabetic nephropathy: an 8-year prospective study. Kidney Int 1992;41:822-8.

4. Yip JW, Jones SL, Wiseman MJ, Hill C, Viberti G. Glomerular hyperfiltration in the prediction of nephropathy in IDDM. Diabetes 1996;45:1729-33.

5. Lervang $\mathrm{H}-\mathrm{H}$, Jensen $\mathrm{S}$, Brochner-Mortensen J, Ditzel J. Early glomerular hyperfiltration and the development of late nephropathy in type 1 (insulin dependent) diabetes mellitus. Diabetologia 1998;31:723-9.

6. Silveiro SP, Friedman R, Azevedo MJ, Canani LH, Gross JL. Five-year prospective study of glomerular filtration rate and albumin excretion rate in normofiltering and hyperfiltering normoalbuminuric NIDDM patients. Diabetes Care 1996;19:171-4.

7. Nelson RG, Bennet PH, Beck GJ, Tan M, Knowler WC, Mitch WE, Hirschman GH, Myers BD. Development and progression of renal disease in Pima Indians with noninsulin-dependent diabetes mellitus. N Engl J Med 1996;335:1636-42.

8. Mauer SM, Steffes MW, Michael AF, Brown DM. Studies of diabetic nephropathy in animals and man. Diabetes 1976;25 (Suppl. 2):850-7. 
9. Schmitz A, Christensen CK, Christensen T, Solling $\mathrm{K}$ : No microalbuminuria or other adverse effects of long-standing hyperfiltration in humans with one kidney. Am J Kidney Dis 1989;13:131-6.

10. Narkun Burgess DM, Nolan CR, Norman JE, Page WF, Miller PL, Meyer TW. Forty-five year follow-up after uninephrectomy. Kidney Int 1993;43:1110-5.

11. Herman W, Hawthorne V, Hamman R, Keen H, De Fronzo R, Newman J, De Stefano F, Striker G, Hirschman G, Agodoa L. Proceedings from the International Symposium on Preventing the Kidney Disease of Diabetes Mellitus: Public Health Perspectives (Consensus Statement). Am J Kidney Dis 1989;13:2-6.

12. Chantler C, Barrat TM: Estimation of glomerular filtration rate from plasma clearance of ${ }^{51}$ - chromium edetic acid. Arch Dis Child 1972;47:613-7.

13. Microalbuminuria Collaborative Study Group: Microalbuminuria in type 1 diabetic patients: prevalence and clinical characteristics. Diabetes Care 1992;15:495-501.

14. Pabico RC, McKeena BA, Freeman RB: Renal function before and after unilateral nephrectomy in renal donors. Kidney Int 1975;8:166-75.
15. Morgensen CE, Christensen CK, Pedersen MM, Alberti KGMM, Boye N, Christensen T, et al. Renal and glycemic determinants of glomerular hyperfiltration in normoalbuminuric diabetics. $\mathrm{J}$ Diabet Complications 1990;4:159-65.

16. Hostetter TH, Olson JL, Rennke HG, Venkatachalam MA, Brenner BM. Hyperfiltration in remnant nephros: a potentially adverse response to renal ablation. Am J Physiol 1981;241:F85-FG93.

17. Silveiro SP, Friedman R, Gross JL. Glomerular hyperfiltration in NIDDM patients without overt proteinuria. Diabetes Care 1993;16:115-9.

18. Gall M-A, Rossing $P$, Skott $P$, Damsbo $P$, Vaag $A$, Bech $\mathrm{K}$, et al. Prevalence of micro- and macroalbuminuria, arterial hypertension, retinopathy and large vessel disease in European type 2 (noninsulin dependent) diabetic patients. Diabetologia 1991;34:655-61.

19. Mogensen CE. Microalbuminuria predicts clinical proteinuria and early mortality in maturity-onset diabetes. N Engl J Med 1984;310:356-60.

20. Brenner BM, Lawler EV, Mackenzie HS. The hyperfiltration theory: a paradigm shift in nephrology. Kidney Int 1996; 49:1744-7. 